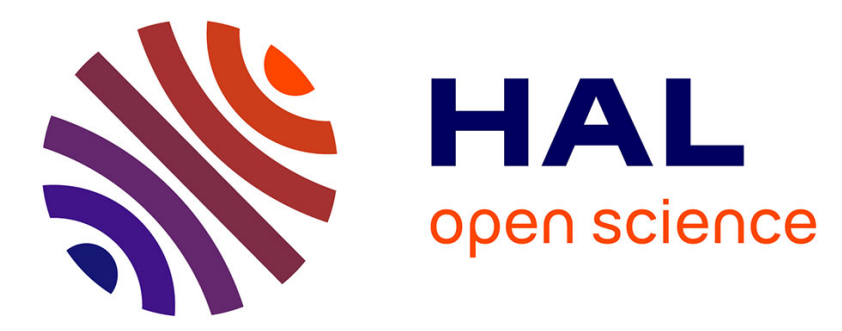

\title{
Institutional Dynamics and Localized Inter-Firm Relations
}

Damien Talbot

\section{To cite this version:}

Damien Talbot. Institutional Dynamics and Localized Inter-Firm Relations. European Urban and Regional Studies, 2000, 7 (3), pp.223-236. 10.1177/096977640000700303 . hal-02375061

\section{HAL Id: hal-02375061 https://hal.uca.fr/hal-02375061}

Submitted on 21 Nov 2019

HAL is a multi-disciplinary open access archive for the deposit and dissemination of scientific research documents, whether they are published or not. The documents may come from teaching and research institutions in France or abroad, or from public or private research centers.
L'archive ouverte pluridisciplinaire HAL, est destinée au dépôt et à la diffusion de documents scientifiques de niveau recherche, publiés ou non, émanant des établissements d'enseignement et de recherche français ou étrangers, des laboratoires publics ou privés. 


\title{
Institutional Dynamics and Localised Inter-firm Relations: the Case of Aerospatiale and the Toulousian Subcontractors
}

\author{
Damien Talbot \\ In European Urban and Regional Studies \\ July 2000, vol.3, pp.223-236 \\ Chercheur au LEREPS \\ Maître de Conférences \\ Université de Metz \\ IUT/TC \\ Ile du Saulcy 57045 METZ Cedex 1 \\ France \\ Phone: 03-87-31-51-52 poste 65-73 Fax: 03-87-31-51-72 \\ E-mail: damien.talbot@iut.univ-metz.fr
}

\begin{abstract}
This article focuses on the understanding of the processes of transformation of non-market collective reference points. In order to do this, we will employ the concept of institutional dynamics, the definition of which will be preceded by a distinction between the concepts of institution and organization. We will seek to validate this definition by the case-study of the "aeronautical branch" of Aerospatiale which, over the last thirty years, has undergone a great evolution in the utilisation of nonmarket collective reference points in its subcontracting relationships. These changes are a result, at least partly, of institutional dynamics.
\end{abstract}

Key words: institutions, organization, institutional dynamics, Aerospatiale, aeronautical subcontracting 


\section{Introduction}

The main issue of this text refers to the functioning of the various modes of coordination implemented by the actors, in order to solve a productive problem. This involves, in particular, updating the role of the collective reference points used by these actors for coordination, whether it is a question of commercial reference points (the system of price) or of non-market reference points (rules, norms, conventions, institutions, etc). Furthermore, it is necessary to integrate the fact that these collective reference points, far from being static, undergo substantial transformations. Indeed, in the empirical case that we will have to analyze, one notes an evolution of the non-market collective reference points used by Aerospatiale ${ }^{1}$ for coordination. It is to the understanding of the processes of transformation of these non-market reference points that this article is devoted.

More precisely, the institution is a concept which defines the non-market reference points very much used in economy, but in very different ways according to the different approaches. At least two large trends deal with the treatment of this concept.

The New Institutional Economy (Williamson 1985, 1998) sees in the institution a system which, visa-vis the weaknesses of the market, ensures coordination between the economic actors by guiding their individual actions. The institution is thus a complement of the market, which takes the form of contracts. And ultimately, Williamson constructed a tool of comparative analysis of the economic efficiency of the modes of coordination which include the market, the hybrid forms (like the cooperation) or the firm: it is indeed an approach of comparative statics (Hodgson 1996).

For American institutionalists (Veblen 1899; Commons 1934; Hodgson 1988), the institution is not only a reference point of coordination of actions, because it also has an effect on influencing the actors' preferences. With this approach, we leave the maximisator paradigm to enter the evolutionist paradigm, the actors hereby developing practices, rules and routines which they adjust according to the alternatives which are supposedly best (Rutherford 1995). It is about a theory which proposes a retrospective vision of change, while insisting on the forces of inertia which ensure continuity. This is the case of the concept of institutional dynamics proposed by Veblen, which places the dynamics of the institutions at the centre of the analysis, contrary to the New Institutional Economy. And it is for this reason that we adopt here the theoretical stance preached by American institutionalists. We will thus be led to define the concept of institutional dynamics, this definition itself being preceded by a distinction between the concepts of institution and organization.

Secondly, we will try to validate this definition by the case-study of the "aeronautical branch" of Aerospatiale, which over the last thirty years has undergone great changes in its method of coordination with its subcontractors. According to us, these changes are a result, partly at least, of institutional dynamics.

More precisely, from the Seventies on one can note the increasing importance of the geographical proximity in the methods of coordination between Aerospatiale and its subcontractors (in particular in 
the Toulousian agglomeration). Generally speaking, the group coordinates with the various actors of the air transport sector (European aircraft manufacturers, subcontractors of various sizes, the French State) in accordance with an institutional framework defined as weaponry logic. And if the latter is characterized by the importance placed on geographical proximity between principal contractors and subcontractors, it is distinguished initially by the fact that the State is a central actor which imposes this same proximity on the public aircraft manufacturer.

However, confronted with the multiple commercial failures to which this logic leads (following the example of Concorde), certain individual actors seek to transform this set of collective reference points, and to work out a new institutional set defined this time as market logic. And the integration of this market logic leads Aerospatiale to rationalize its subcontracting relationships. Thus, the aircraft manufacturer selects its subcontractors mainly according to criteria of costs, without systematically favouring the geographical proximity between the principal contractor and the subcontractor. Consequently, the geographical proximity is no longer required between Aerospatiale and its subcontractors.

\section{Institutions: the cognitive level}

After having given a definition of the institution as a set of collective cognitive practices, we will see that its aim is to guide the actions of individuals.

Institutions as collective cognitive practices

American institutionalism considers, following cognitivist developments ${ }^{2}$, that cognition and action are clearly interdependent. However, according to Varela, Thompson and Rosh, cognition does not come before the action: "far from being the representation of a pre-given world, [cognition] is the link between a world and a spirit formed from the history of the various actions that brought about one's being in the world" (1993, p.35). This argument incites us not to remain not at a single level of behaviour, but to integrate cognition. Thereafter, from an institutionalist viewpoint, players are no longer alone at the center of the analysis, because it is the knowledge of their representations that permits an understanding of their behaviours.

In effect, during one's actions, each individual builds him or herself an image of the world, a representation. "Because our cognitive capacities cannot match the complexities of our situation, we must act on the basis of representations (...)" (Loasby 2000, p. 298). The role of this representation is to convert information into knowledge, to give meaning to the data collected. Social status is entirely contained in this conversion: if the interpretation of data is an individual matter, it is strongly influenced 
by the social context (Hodgson 1988). And Loasby adds that "(...) we do not have the time or ability to formulate more than a very small proportion of these representations and procedures for ourselves, and therefore often rely on those which appear to be used by other people" (2000, p. 298). This contributes to the construction of a vision of common reality in a social group.

In fact, the various representations maintained by the individual are not simply juxtaposed one next to the other. According to cognitive sciences, they are organised as models (Piaget 1970; JohnsonLaird 1994). As is the case for the representations they order, these groups are carried by individuals, but are impregnated by the collective. They can be manipulated to construct and solve an action issue. This means that representations guide behaviours, and that knowledge transforms into action.

This paper maintains the idea that these structured groups of representations can be understood as if they were institutions, thereby adopting a Veblenian perception of institutions.

Indeed, Veblen sees in the practice of thought a definition of the institutions, understood in this case as "settled habits of thought common to the generality of men", (1909, p. 239). More precisely, one can understand these practices as structures of thoughts which occur in the absence of conscious choices (Waller 1988), and which consequently enable us to face the complexity of life. Having a prior existence, the practices increase the efficiency of the action by making it possible for the actors to concentrate on resolving certain problems. One can attribute three dimensions to them: they are the base of all learned behaviours ${ }^{3}$, they represent general rules and are a historic product (Renault 1995).

In this sense, the practices of thought support the concept of representation when seen as an image of the world, if the representation is of a subjective, collective and stable nature. Thus, we can consider that this concept explains the vision of Veblen, the perennial and generalized representation being the contemporary counterpart of the practice of thought ${ }^{4}$.

Thus, if the institutions are practices of thought, one can also define them as sets of representations: "(...) the generalization of representations, their standardization, tends to constitute what Veblen calls practices of thought, which confers a certain stability on them. They become institutions" (Dutraive 1993, p. 28).

On the whole, we consider institutions to be socially shared practices of thought, or subjective, collective and stable representations. All things considered they are collective cognitive practices.

\section{Functions of institutions: the control and release of the action}

These collective cognitive practices are normative models which define what seems to have to be done (Hodgson 1988). Moreover, they constitute an informational support necessary to realize an action in a partially known and understood economic environment. Like reference points of coordination, institutions are thus at the same time constraints and resources for the action (Corei 1995). The first aspect refers to the control of the action, the second to its release (Commons 1934), a 
release made possible by the coherence provided by this same control of the action and the informational content of the institution.

But if the institutions determine the action, that does not mean that they underlie it in a deterministic and mechanical manner (Hodgson 1997). Indeed, the institutions guide the action without producing it. There is certainly a freedom of action, an intention induced by the actors which is expressed in the channels opened by the institutions (Sjöstrand 1995).

Let us add that institutions, as regulating authorities which limit the individual's will, can take the form of rules (Groenewegen 1995). According to Dewey, the rule must be understood as an institution formulated and accepted by the actors who apply it (Renault 1995): it would be a codified institution.

We have just proposed a definition of the institutions which considers them to be cognitive. And if on the side of cognition one finds institutions and rules, it is necessary to place organizations and routines on the side of the action.

\section{Organizations: the level of the action}

What place can one attribute to the actions in the institutional framework which we have just described? The answer to this question lies in the intentions of the individuals, intentions which we have just emphasized remain complete with regard to the institutions. The individual maintains a freedom of action regarding the influences which result from the institutional context, which implies in particular the possibility that he can modify it. In the terms of Livet and Thevenot (1994), it is a matter of taking into account the repercussions of the unknown risks of the action on the representations.

With this intention, we adopt the same approach here as previously: after having defined the organizations, we will describe their purpose, which will enable us to clarify the link with institutions.

A definition of the organization: a collective action directed towards common objectives

The coordination of the actors engaged in an action occurs due to the putting in place "(...) of behaviours particular to a certain group of persons who conform to it. These persons are identified then in the form of organization, that is of an entity of social coordination, whose boundaries are relatively simple to identify, and which functions in an enduring manner so as to achieve a goal or a set of objectives shared by economic actors who find, in this objective, their reason for belonging to the organization" (Jayet 1996, p. 251).

The voluntary participation of this group of persons is a assent to contribute to the common goal. But this assent result from conflicts and arrangements : it is an institutional product. Therefore, the 
organization can be understood as a set of stable behaviours, a stability produced by the institutions. The actors who form the organizations act in the space opened by the institutions and in the space opened by their interpretation, since "(...) the organizations constitute a space of definition of the practices and strategies of the actors within a set of rules given by the institutions" (Kirat and Lung 1995, p. 6). And Loasby specifies that organization (like a firm) "(...) may be seen as a response to the cognivite limitations of individuals. (...) It provides a framewok for the co-ordination of distinctive specialities through the development of locally-appropriate institutions, and the opportunity to discover who may be regarded as an authoritative source of what communications; and it consequently provides an environment in which capabilities may be developed in a coherent and suitably-oriented fashion" (1999, p. 10).

These controlled actions imply the production of both routines and rules by the organizations. By this double production, the organizations put at the disposal of their members the tools with which to solve a problem, and this is their purpose.

Functions of organizations: solving problems in order to achieve common goals

On the basis of institutions produced by their members, organizations can produce rules to their advantage, while trying to direct the actions of individuals. This creation and this imposition of rules on the participants of coordination are an aspect of the exercise of power. Generally speaking, the rules are always connected to this latter in that they control the conflict-consensus relationship. The rules indeed "serve a power", according to Reynaud (1993, p. 42). Thus, this power authorizes its holder to transform collective cognitive practices into explicit rules, and to impose them on the participants of coordination. As an example one can quote the case of certifying organisations of civil aviation ${ }^{5}$ which decree the safety regulations to be complied with imperatively by each model of aircraft, under penalty of grounding (and thus of sale). These same rules, which differ from one country to another, can favour the local manufacturer to the detriment of his competitors.

More generally, all organizations produce routines when applying rules. It is indeed possible to continue with the example of certifying organisations of civil aviation, in order to note that these organizations themselves carry out the necessary checks in order to grant certification: they thus also generate the routines which make it possible to observe the rules that they promulgate. This is the position of Menard (1990), for whom the organizations ensure the implementation of the rules resulting from institutions. A rule is a statement which must make it possible to find the solution but which does not give it (Reynaud 1997). Routines are therefore these solutions which apply these same rules. More precisely, for the evolutionary authors, these routines are "models of interactions which constitute efficient solutions to particular problems" (Dosi, Teece and Winter 1990, p. 243). They are composed of coded sequences determining a sequence of decisions and behaviours (Menard 1994). In this sense, they are practices of behaviour (contrary to rules, routines are about 
the action) which store a tacit and lasting know-how.

The second phase now consists in adopting a dynamic vision of the distinction between institution and organization that we have just proposed, for as Guerrien (1990) notes, "(...) the study of institutions and organizations can only be done in a precise social and economic environment, progressing from observed situations and not from completely imaginary states and individuals, out of all historic context" (p. 107).

\section{Concept of institutional dynamics}

The concept of institutional dynamics that we develop here seeks to grasp the evolutions of the institutions induced by the actions carried out by the members of organizations. We opt for a vision of the change in terms of open cumulative process where causes and effects are connected, and where each phase of the institutional evolution results from the preceding one, "(...) without definitive completion or absolute beginning" (Delorme 1997, p. 99). Our aim here is to give an account of the evolution of institutions rather than their emergence ex nihilo. That thus means that we will suppose the existence of institutions at the start of the analysis, the latter describing their process of transformation.

We tackle the understanding of institutional dynamics through the factors which lead to its activation. In our opinion, it is possible to identify two types of behaviours of actors which can cause an institutional dynamics: adopting new routines by processes of learning and exercising a power. These two sources lead to two complementary definitions of institutional dynamics.

First source of institutional dynamics: a change of routines by learning ${ }^{6}$

We have Veblen to thank for having been the first to put the emphasis on the role of technology in institutional dynamics. He establishes a fundamental distinction between technology and institution, leading to an understanding of institutional dynamics as a result of the technological change.

More precisely, Veblen (1899) explains that it is necessary to compare the progressive action of technology with the inhibiting action of institutions, technology being the main force of economic and social evolution. As we have seen, the institutions, as constraints, have the role of establishing an agreement in the action, a unit of behaviour. They thus represent the stable aspect of the environment in which people act, by materializing the heritage of the system. However, the action of technology has a destabilizing effect, changing the old institutions and submitting the need for new ones.

More recently, this intuition has been developed by the evolutionist movement (Penrose 1952; Nelson and Winter 1982; Nelson 1995) which in particular has demonstrated that technology, like 
knowledge, is materialized in routines. Among these routines, it is advisable to distinguish static routines, refering to the repetition of practices already in place, from dynamic routines which are directed towards new learnings (Dosi, Teece and Winter 1990). And confronted with a changing environment, the routines accumulated within the firm evolve by natural processes of selection and transformation, according to a trajectory determined by technological opportunities (Dosi 1988). Again a similarity with the Veblenian analysis of change exists, the evolutionary authors explaining that a transformation of routines by learning is a factor of endogenous evolution of the firm?

On this basis we can now suggest a first definition of institutional dynamics: the actors who make up the organization create new routines by learning in response to the appearance of new problems, new information or new techniques, these new routines gradually eroding the institutions in place, until new ones are constituted.

However, for evolutionary authors routines "are thought out and characterized without reference to unspecified social and historic content" (Coriat and Weinstein 1995, p. 137). With regard to this absence of social dimension, the role of conflict in the change, and consequently that of power, is completely eliminated from the analysis, whereas for American institutionalists it constitutes another source of institutional dynamics. The process of selection here is artificial.

\section{Second source of institutional dynamics: relations of power}

In certain cases actors can seek to make institutions, and in particular rules, evolve directly in order to achieve their goals. The taking into account of this example implies introducing into the analysis the relations of power between the actors, as done by American institutionalists. Thus "(...) by considering that the conflicts and the relations of power between social groups are essential to the comprehension of economic and social dynamics, the institutional analysis develops a problem in which the idea of voluntary social regulation of the institutional evolution constitutes a major theoretical and practical challenge" (Bazzoli and Dutraive 1995, p. 52). The technical change is no longer the only driving power of the economic and social change, the change being a result, partly at least, of the dynamics of the relations of power. It is indeed "(...) a question of putting the accent on the active role of individuals, groups and legal authorities and on the conflicts between groups with asymmetrical powers, which are regarded as the major process of the evolutionist adaptation of the institutions (...)" (Clerc et al. 1994, p. 202). Thus, certain actors seek to impose their will on others, thereby generating conflicts solved by collective action.

For American institutionalists this double dynamics of appearance and solution of conflicts becomes the major process in the evolution of institutions. Indeed, these various solutions can lead to the introduction of new institutions, and in particular of new rules, which in this case will appear to be answers to the conflicts. Of course, these rules are promulgated by actors controlling these conflicts, i.e. by actors who hold power and who have at least the capacity to authorize or not new rules which 
would not emanate from them, and even the capacity to impose rules that they could be led to create. Institutional dynamics is then understood, and it is our second definition, as a set of processes of production and imposition of institutions, processes carried out by the holders of power who make pragmatic decisions according to the objectives that they set. Here, institutional dynamics is imposed by certain actors on others.

In short, it is possible to synthesize the various processes of institutional dynamics as follows:

- the organizations adapt to the multiple emergences of new techniques, new information, or of new problems by transforming their routines. These innovative routines can cause new conflicts on the rules to be observed, and a questioning of the existing institutions by a progressive erosion: it is the first source of institutional dynamics;

- another possible situation, the actor who holds the power creates his own rules on the basis of institutions which he has produced, and imposes them on others. Those who are subject to the power thus experience a change in their institutional framework: it is the second source of institutional dynamics.

Clearly, these two processes are complementary: one can succeed the other, or they can even be carried out simultaneously. The example which we will analyze in the continuation of this work deals with a productive organization, in fact Aerospatiale, which has modified its institutions and its rules in response to new knowledge (first source), then imposes them on its subcontractors (second source).

More precisely, we proceed in this empirical part in two phases. Initially, we will show that the relation of subcontracting, from the Sixties until the end of the Eighties, was founded on a strong geographical proximity between the principal contractor and the subcontractor, a proximity which is currently stabilized. Secondly, once this observation has been noted, we will devote ourselves to the study of the causes of this stabilization. It will appear that it is a result, partly at least, of an institutional dynamics in the sense in which we have just defined it, marking the transition from a weaponry logic to a market logic.

\section{The relation of subcontracting from the sixties until the end of the eighties: a geographical proximity between Aerospatiale and its subcontractors}

After having analyzed the reasons for the construction of a geographical proximity between the industrial group and the subcontractors, we will note that today this proximity is no longer 
systematically sought by Aerospatiale.

A geographical proximity imposed by the French State within the context of a weaponry logic

To understand the setting up of such a proximity requires beforehand a characterization of weaponry logic, which we understand as a particular set of institutions. From the Sixties the aircraft industry has been perceived as an adventure which instills in people, at least in France, a national feeling of pride; it is also a strategic challenge for the nations, the control of this activity conferring on the country its military, industrial and technological independence. On the basis of these characteristics, two institutions, in the sense in which we defined them, appear to constitute a weaponry logic (Talbot 1998): on the one hand, an efficient aircraft is an aircraft which performs well technically, on the other hand, the State is the central actor in this industry. At least two rules governing the relations between the actors of the aircraft industry are added to these institutions: the authorization of budgetary divergences since the cost of the aircraft is not a primordial criterion; the State fixes the characteristics of the aircraft and designates the industrialists concerned with a programme, and can, for this reason incite the latter to support the industrial materials located around their establishments.

In this context, the State makes the public group Aerospatiale apply its territorial development policy: Aerospatiale takes on the role of organizer of local industry, in the sense that the work that it delegates constitutes a material resource allotted by the State which it is necessary to divide between Aerospatiale and the subcontractors. Here it is necessary to look at a third fundamental rule of weaponry logic, which governs the relations between the French State and the public aircraft manufacturers. Thus, until the end of the Eighties, one witnessed a concentration of the subcontractors around the four sites of the "aeronautical branch" of Aerospatiale ${ }^{8}$, which are Méaulte (Paris area), Nantes, Saint-Nazaire and Toulouse (Figure 1). 


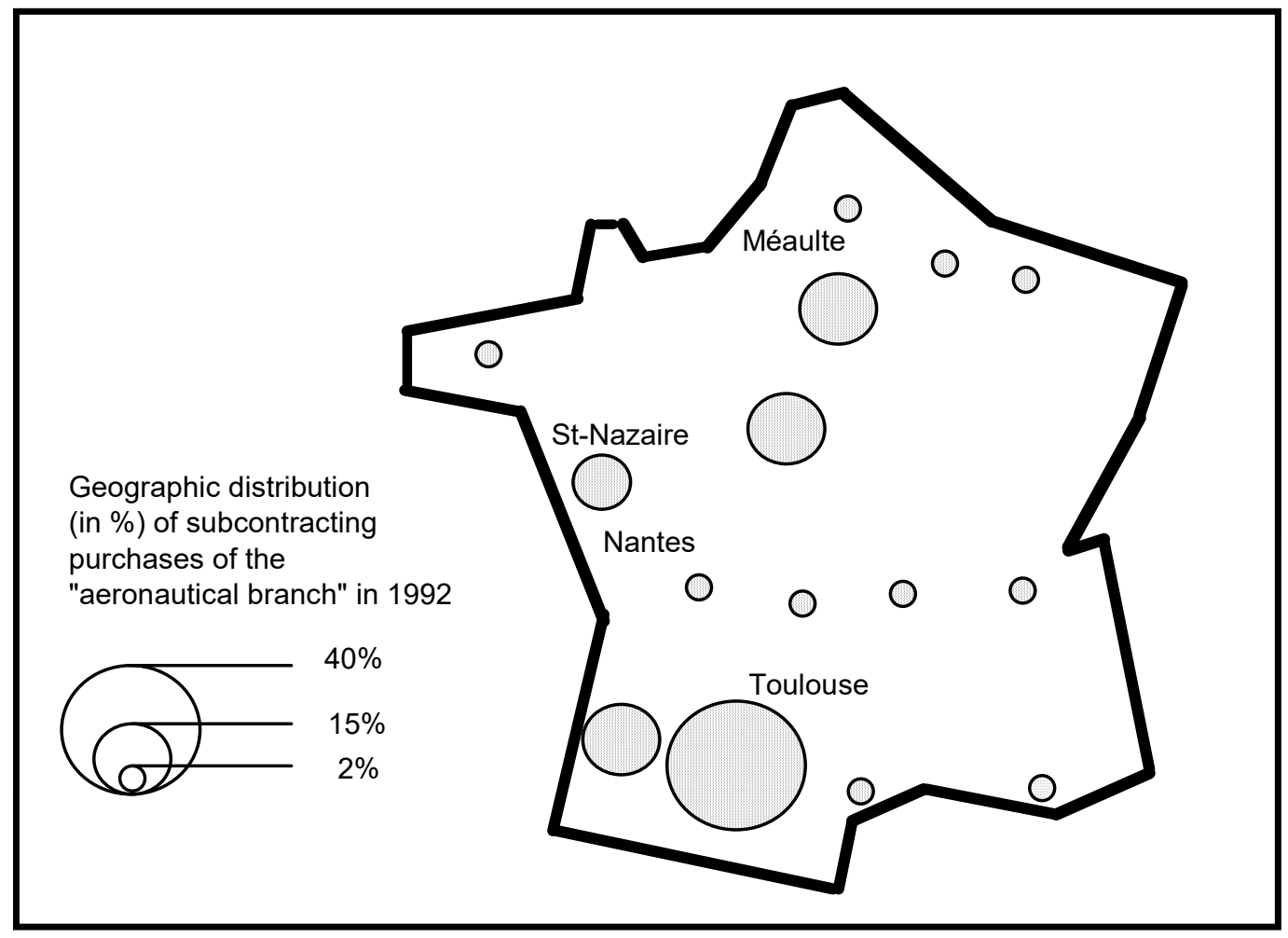

Sources: Aerospatiale, P. Beckouche (1996), p. 177.

Figure1 Subcontractors of the "aeronautical branch" of the Aerospatiale group in 1992

Figure 2 enables us to note that in the Midi-Pyrenees area, it is mainly in the area around Toulouse that an increase in the number of workers can be seen during this period (Beckouche 1996). According to INSEE, between 1982 and 1990 there was a reduction in the number of employees, except in Tarbes and Toulouse, the two sites where Aerospatiale is implanted in Midi-Pyrenees. In 1982, Haute-Garonne employed half of the employees of the sub-contracting firms of the air transport and space sector in the area and in 1990 this number almost tripled, whereas it stagnated or even decreased in the other departments. $56 \%$ of the workers in the whole area (three-quarters in HauteGaronne) are based in the communes of Toulouse, Blagnac and Colomiers, whereas this proportion was only $30 \%$ in 1982 . 


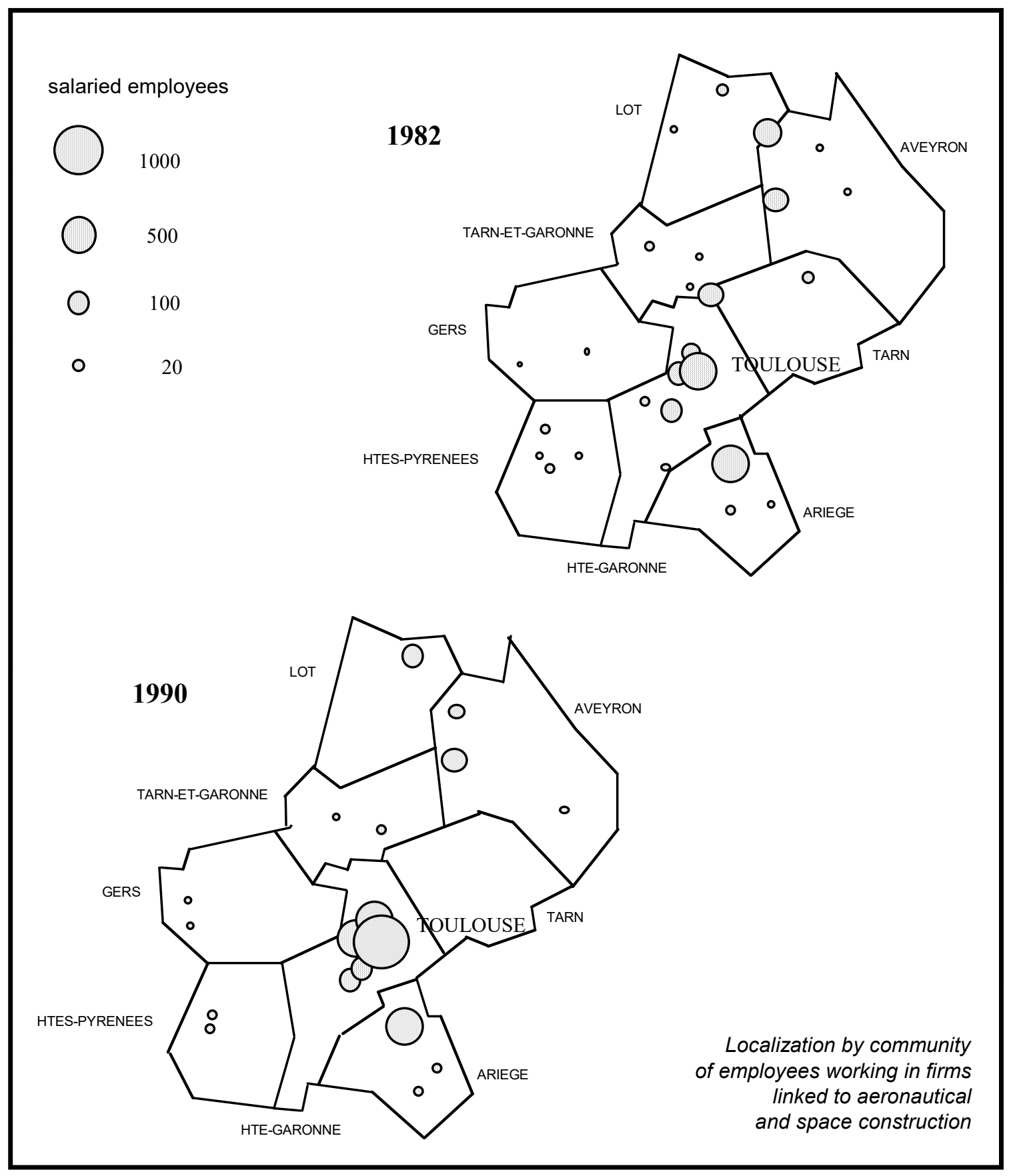

Source: INSEE, Relief n², 1992.

Figure 2 Spatial concentration of subcontracting in Midi-Pyrenees

An observation: geographical proximity is no longer a criterion in the selection of subcontractors

In the opinion of all our interlocutors ${ }^{9}$, the geographical proximity between Aerospatiale and its subcontractors is no longer required in the relations of subcontracting. Thus, the process of 
concentration of subcontractors around Aerospatiale's factories was halted: one encounters the same concentration in 1996 as in 1990 in the Toulousian agglomeration with $83 \%$ of the subcontracting employees in 1996 (Fogiel et al. 1994), and 85\% in 1990 (Beckouche 1996). Figure 3 shows a stabilization of the intra-regional movements over the last ten years, compared to the Eighties. The Toulousian agglomeration is experiencing an increasing activity, but not more than in the rest of the area: it does not have the same capacity of attraction as in the previous decade. Consequently, the geographical proximities that can be noted today are more the result of history than of a current desire of the principal contractor.

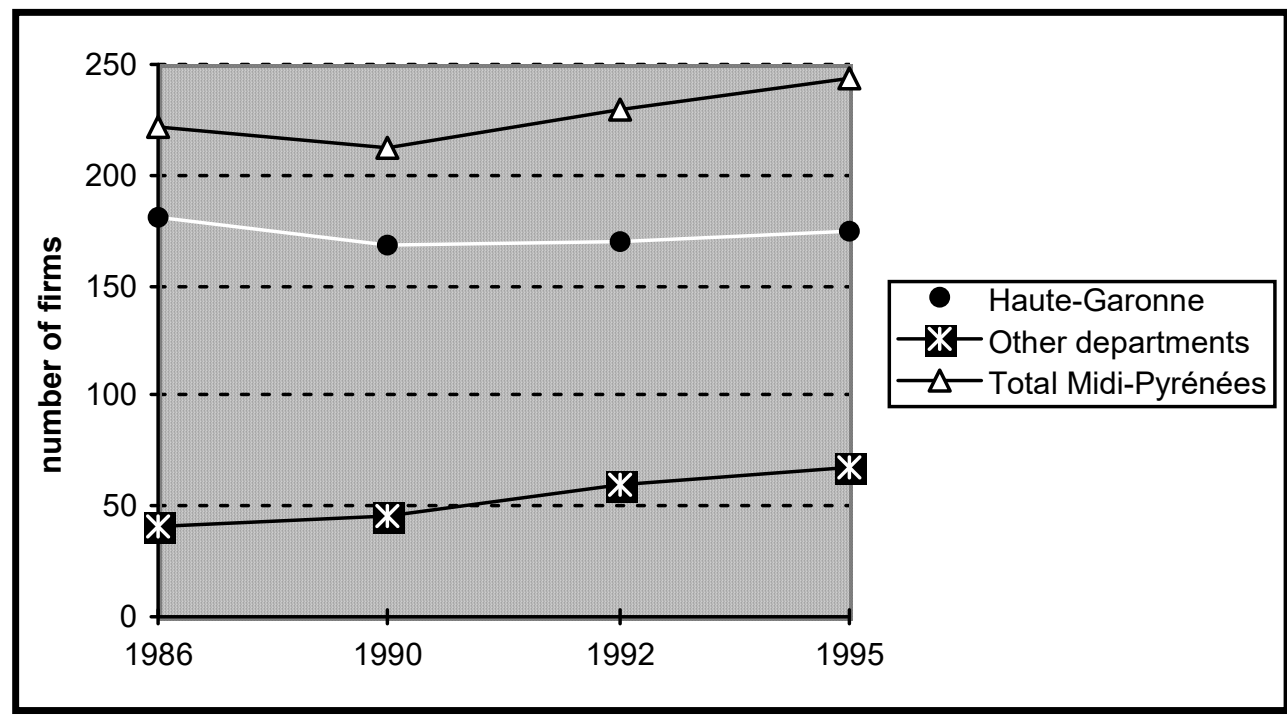

Sources: INSEE Files, aeronautics and subcontracting in Midi-Pyrenees, investigations 1987 ( $\left.n^{\circ} 35\right), 1991$ $\left(n^{\circ} 50\right), 1993\left(n^{\circ} 64\right), 1996\left(n^{\circ} 81\right)$.

Figure 3 Localization of firms linked to aeronautical and space construction (number of firms)

How can such a phenomenon be explained? Two complementary explanations can be given:

- on the one hand, the growth of international subcontracting has taken a great amount of work from Toulousian subcontractors. Two factors contribute to the growth of this international subcontracting. Since the beginning of the Eighties, it has been necessary to concede more and more agreements of production compensation to obtain markets. The indemnity clause binds the purchase of the aircraft to the supply of equipment by the industry of the country customer, equipment which must be installed on sold aircraft. Let us quote the example of Dasa which in 1994 sub-contracted the production of elementary parts for vertical stabilizers of Airbus to Chinese industrialist Xian Aircraft ${ }^{10}$. To this first factor is added the fact that the relocations in the dollar area make it possible to make good the losses incurred due to a weak dollar, while in certain cases employing cheap labour. Thus, Dasa can influence the assignment of the production of parts to 
firms in the dollar area: it is what happened to Labinal, which obtained an important contract of electric wiring of A320s on the express condition that the equipment supplier established his factory in Mexico.

On the whole, international subcontracting represented about a third of the load of subcontracting managed by Aerospatiale (Kechidi and Panadero 1994) at the beginning of the Nineties, whereas in the Sixties it was quasi non-existent;

- in addition, the disappearance of the rule of support for local industrial materials does not encourage the lasting maintenance of this geographical proximity. This disappearance is a result of the progressive disengagement of the French State from the aircraft industry, and of the need for Aerospatiale to widen the choice of subcontractors in order to reduce its purchase costs. More generally, we are confronted with an institutional dynamics, marking the transition of a weaponry logic towards a logic of market. We return in detail to this point.

\section{Institutional dynamics at the origin of the transformations in subcontracting relationships}

It is possible to identify two distinct periods in the progress of institutional dynamics. In a first phase, certain individuals, confronted with the limits of weaponry logic, sought to give new answers, in particular organisational. And by their new behaviours, these individuals will make the institutions of the weaponry logic evolve towards a new institutional group which we described as logic of market. This is the first source of institutional dynamics which, at this stage, concerns mainly the industrial groups. In a second phase, Aerospatiale imposes new rules resulting from a logic of market on its subcontractors who in turn see their institutional framework changing. This is the second source of the institutional dynamics.

The beginning of institutional dynamics, resulting from a change of organisational routines

In order to clarify the limits of the actions induced by the weaponry logic, and consequently the reasons for the appearance of this institutional dynamics, let us take the significant example of the programme Concorde. The reasons which governed its launching show that this programme is the product of a weaponry logic. Indeed, the Sixties correspond to a period when the sales of Caravelle tailed off: the French civil aircraft manufacturers thus required the State, as a customer, to provide them with work. To this was added the de Gaullian will to establish national prestige. Lastly, it was a full period of European construction. The French State had the idea to build a prestigious, supersonic 
aircraft in cooperation with a British partner.

The weaponry logic which prevailed during the launching of the programme remained prevalent in the phase of realization. And very quickly, it appeared that even though the technical success was undeniable, the commercial failure was every bit as great. Egalitarian cooperation leading to industrial duplications, deviation from the costs of R\&D, no precise timescale set up, a rigid and complex hierarchical structure and, especially, no detailed market research, are as many reasons which explain this failure. More basically, it is indeed the representation according to which a good aircraft is a technically powerful aircraft, which is at the root of such erroneous actions. This collective cognitive practice is foremost in the minds of all the actors of the air transport sector, leading these actors to seek only technological performance, to the detriment of organisational efficiency and cost. And the failure of the programme Concorde challenges the relevance and the efficiency of this institution.

This observation is made by certain individuals, like the German Kracht and the Frenchman Beteille, who propose the installation of new organisational routines. More precisely, Kracht was an engineer in Nord Aviation, before directing the Franco-German military programme Transall, he too being an example of the deviations associated with egalitarian style cooperations. In a strong position thanks to this experience, he suggested a new industrial organization based on a simple interface between the industrialists and on a single assembly line (the GIE Airbus), which he succeeded in imposing in the name of industrial efficiency. As for Beteille, he took on responsibility for the commercial efficiency of the programme Airbus by addressing the airlines directly in order to respond to their demand effectively. On entering Sud Aviation after the Second World War, he deplored the fact that during the programme Caravelle, no version adapted to the needs of the American companies, which at one time were interested in the aircraft, was proposed (Picq 1990). These individuals could moreover count on the support of several high-ranking French civil servants (Muller 1988), since the obvious failures of the preceding programmes made them more receptive to the new proposals of an industrial and commercial nature. Thus, for the first time, new behaviours transgressing the rules of weaponry logic appeared. Here, we are confronted with the first cause of institutional dynamics, that is to say, where new problems and new information lead industrialists to set up, by processes of learning, new routines which erode little by little the institutions in place.

One of the consequences of this construction of new organisational routines refers to the fact that, for the first time, it is no longer the State which defines these characteristics but in fact the industrialists themselves, depending on commercial requirements. And in a general way, it should be noted that the role of the State has been reduced considerably, leaving Aerospatiale the ability to impose a new rule of selection of its subcontractors.

Imposition of a new rule of selection by Aerospatiale on the subcontractors

In a weaponry logic, the State is at the same time customer, shareholder and financor of the 
industrialists. In a logic of market, it maintains mainly this last role. Let us examine these three functions point by point:

- the State as a customer: in the field of civil aviation, the State is only a customer if he is the principal shareholder of an airline, which is not very common worldwide. It is no longer in a situation to be able to determine the characteristics of an aircraft intended for a market of which it does not form a part and which it does not know, at the risk of perpetuating the failure of the Concorde. As regards civil aeronautics, the State refers henceforth to the recommendations of the GIE Airbus;

- the State as a shareholder: unique in Europe, the French State remains main shareholder of Aerospatiale. But it is known that this latter, during the merger at the beginning of 1999 with Matra Hautes Technologies, is in fact privatised. From now on, it can no longer appoint the manufacturers taking part in a programme;

- the State as a financor: this last role remains intact, even if the State openly expresses its desire to disengage, in a general context of reduction of expenditure. However, this type of intervention remains very frequent, the high costs and the very important risks associated with the launching of new products being at the base of public support for aeronautics, aswell as the military, industrial and technological stakes involved.

This progressive disengagement of the State from the civil air transport sector means that the State cannot impose on Aerospatiale the rule of support for local industrial materials. Consequently the industrial group can widen the search for subcontractors to the whole of the country, giving up its role of public support. Henceforth, Aerospatiale selects subcontractors who provide a high return in terms of price, since price becomes a fundamental criterion of selection of subcontractors in a logic of market.

Indeed, if in a weaponry logic an aircraft must initially be of high performance, in a market logic the central institution refers now to the collective representation according to which this same aircraft must be sold. In a logic of market, it is not the technical performance which is required as in the case of the programme Concorde. Here, a swing of the priorities in the collective representations can be seen: technology should be used only if it confers on the product a commercial advantage. It is thus not a rejection of techniques which can be observed, but rather a reorientation of the aim of these techniques, which must above all favour the sales of the aircraft. And in a market which is especially attentive to price, any innovation aims to bring about a signficant reduction of the costs of exploitation and maintenance for the airlines. Henceforth, a good aircraft is no longer simply a high performance 
aircraft, it is first and foremost a product which sells. This is definitely an example of a changing weaponry logic.

Consequently, the sale prices of aircraft agreed with airline companies encourage manufacturers to reduce their purchase costs, in order to maintain their levels of profitabilit: it is in particular the case of Aerospatiale which, from the beginning of the Nineties, sought to reduce its costs by $30 \%$ in 5 years (Talbot 1998).

In order to achieve this goal, Aerospatiale rationalizes the relation of subcontracting by selecting the subcontractor, not according to its geographical situation, but according to its capacity to offer a service of quality, within time limits and in particular, at interesting prices. The group uses its power of principal contractor to impose this new rule of selection on subcontractors ${ }^{11}$. We are faced, in this precise case, with the second source of institutional dynamics.

So, it is no longer enough for a subcontractor to be located near the Toulousian establishments of Aerospatiale to be given work. The geographical proximity can even be considered by Aerospatiale to produce negative effects: the principal contractor can take a stance in the event of social conflicts, or the subcontractor, too accustomed to the presence of the principal contractor and basing itself on the quality of past relations, can omit to seek a necessary diversification of customer and product.

This new rule of widened selection is applied by the construction of new routines organizing the productive relation, and which limit the need for face to face encounters. One indeed observes the appearance of very complete written contracts which formalize the relations, specifying for example the conditions of supply, the division of information, quality control, time limits and delivery procedures, the insurances and the guarantees to be taken out in the event of default, the price and methods of payment, the intellectual property, the terms used by addition of a glossary to the contract, etc.

The gradual installation of tools of communication put in place by Aerospatiale can be added to this formalization, rationalizing further the relation. We identify at least three types of tools:

- a close following-up of the subcontractors introduced by Aerospatiale towards the end of the Eighties. This follow-up took the form of the "Programme Meeting Review", in which one can see a set of procedures of consistency making it possible to rationalize the communication of information, in the form of monthly or semi-monthly meetings (Larre 1994). They thus make it possible to decrease the uncertainty inherent in any relation;

- at the same time, a tool of coding and standardization SPIDER (System of Computerized Production of Gathered Elements) which groups together by families the parts used within the group, is applied in subcontracting relations (Kechidi 1996);

- finally, from the beginning of the decade one has witnessed the setting up of a data-processing network of all subcontractors thanks to EDI (Electronic Data Interchange). It is a homogeneous 
system of communication used in-house, but also with the subcontractors. For example, thanks to EDI, Aerospatiale was able to set up the Greenloop approach which allows the supply in restricted flows ${ }^{12}$ : the plans of supply and the calls of delivery are automatically generated at computerized application level of Aerospatiale and are transmitted to the subcontractor by EDI.

These tools of communication limit the expensive and complex procedures of interface by the perfecting of similar technical norms, of an identical production management of the compatibility of each one's materials, and by the opening to the subcontractors of data banks (Larre 1994). At present, approximately 200 companies throughout the world benefit from these tools which, by facilitating the long distance communication between the firms, limit the need for geographical proximity.

\section{Conclusion}

We proposed a definition of institutional dynamics which we have shown could result from the activity of learning of the actors, but also from relations of power. And in the case of Aerospatiale, we identified two periods in the development of this institutional dynamics where each one of the sources prevails.

Thus, the phenomena observed in the first phase refer to an awareness, at the beginning of the Seventies, by certain individuals of the limits of the weaponry logic: it is about the first source of institutional dynamics, based mainly on the mechanisms of learning. Faced with the problems arising in particular from the commercial failure of the programme Concorde, new organisational routines were proposed by some individuals. These new routine behaviours gradually eroded the institutions in place until new ones were formed.

In a second phase which began towards the end of the Seventies, Aerospatiale modified the rules of the relation of subcontracting, in particular the rule of selection, thus exercising its power: it is about the second source of institutional dynamics, based mainly this time on the relations of power. And this phase is currently continuing.

From this, the question of the scope of this dynamics arises. Will the air transport sector remain a symbol of power and domination for the States, or will it be transformed into a more standard industry? Will the French State for example, with a view to reducing expenditure, continue its financial disengagement, or will it seek to transform the commercial success of Airbus into a political success? Without closing this debate definitively, it appears that the States at present retain a considerable role in this industry while at the same time disengaging themselves, which may seem contradictory: thus, the launching of the very large jumbo jet A3XX is a result partly of a European political willingness, whereas at the same moment the French State privatised Aerospatiale. This shows in any case that 
the weaponry logic, certainly in an attenuated form, remains present in this industry. Here, two logics overlap, an institutional dynamics which is not necessarily either radical or final.

\section{notes}

1 Actually integrated in EADS after the merger with Matra Hautes Technologies at the beginning of 1999.

2 For example psychology, linguistic or computer science.

3. In order to progress it is indeed necessary to transform a significant part of acquisitions into practices.

4. Moreover, Hodgson attributes the same purpose to the practices as to the representations: "without such habit, agents cannot perceive or make use of the data received by their senses " (1998, p. 183).

5. FAA in the United States, CAA in the United Kingdom, DGAC in France, etc.

6 . At this stage of the reasoning it is necessary to make a distinction. Concretely, during the transformations of routines, three situations arise: either this change in the usual behaviours is compatible with the existing institutional framework, or an incompatibility becomes clear and the institutions proving to be resistant to the change block the change, or finally the institutions evolve as a consequence of this incompatibility. In the first situation, the dynamics is simply behavioural, in the second it is stopped, and in the third it is described as institutional. Our analysis refers here to this last situation, the only one to affect the dynamics of the institutions.

7. In a more general way, Foss (1998) sees in Veblen a precursor of the competence-based approach of the firm.

8. This proximity allows personal contacts that are as much sources of information, especially for subcontractors (Grotz and Braun 1997).

9. We conducted about forty interviews in which this question was raised with interlocutors working in particular within Aerospatiale, and with various Toulousian subcontractors.

10. Air \& Cosmos, $n^{\circ} 1637$ - December 1997.

11. The relation of subcontracting is indeed by nature an asymmetrical relation: control over the end product, inequalities concerning technical skills, size, financial resources, are as many aspects favorable to the principal contractor. Consequently, on the basis of this asymmetry, its power is fully expressed by the unilateral determination of the design features of the product, of the conditions of its realization, the norms of quality, the economic conditions of the exchange relating in particular to the distribution of the surplus (Larre 1994).

12. Only the supplies are carried out in restricted flows, and not the production: consequently, the subcontractor stores the products himself. As for the transportation time, a few days are still necessary once the order is placed: there again, geographical proximity is not a pre-requisite. 


\section{References}

Bazzoli, L. and Dutraive, V. (1995) Dynamique technologique et institutionnelle dans la pensée institutionnaliste américaine: les enjeux de la maîtrise sociale, in M. Baslé, D. Dufourt, J. A. Héraud and J. Perrin (Eds) Changement institutionnel et changement technologique. CNRS Editions, Paris, pp. 51-67.

Beckouche, P. (1996) La nouvelle géographie de l'industrie aéronautique européenne, L'Harmattan, Paris.

Clerc, A., Perisse, M. and Villeval, M. C. (1995) De l'organisation externalisante à l'organisation interactive, le jeu des institutions dans le changement, in J. H. Jacot (Ed) Formes anciennes, formes nouvelles d'organisation. CNRS Editions, Paris, pp. 182-208.

Commons, J.R. (1934) Institutional Economics. Its Place in Political Economy, The MacMillan Compagny, new edition 1990, Transaction Publishers, New York.

Corei, T. (1995) L'économie institutionnaliste, les fondateurs, series Economie de poche, Economica, Paris.

Coriat, B. and Weinsten, O. (1995) Les Nouvelles Théories de l'entreprise, Le Livre de Poche, Paris.

Delorme, R. (1997) Évolution et complexité : l'apport de la complexité de second ordre à l'économie évolutionnaire, Économie Appliquée 50: 95-120.

Dosi, G. (1988) The nature of the innovative process, in G. Dosi, C. Freeman, R. Nelson, G. Silverberg and L. Soete (Eds),Technical Change and Economic Theory. Pinter Publishers, London and New York, pp. 219-238.

Dosi, G., Teece, D. and Winter, S. (1990) Vers une reformulation des frontières de la grande entreprise : la notion de cohérence, Revue d'Économie Industrielle 51: 238-254.

Dutraive, V. (1993) Les fondements de l'analyse institutionnaliste de la dynamique du capitalisme, thesis, Université Lumière Lyon II.

Egidi, M., Marengo, L. and Narduzzo, A. (1994) On the origin and nature of organizational routines: some evidence from experiments, The Eunetic Conference Evolutionary Economics of Technological Change: Assessment of results and new frontiers, Strasbourg.

Fogiel, P., Porteu, E., Rabine, D. and Bourgeois, T. (1994) Étude d'implantation géographique sur les sous-traitants et fournisseur du secteur aéronautique et spatial, Observatoire de la SousTraitance des Industries Aéronautiques et Spatiales, July.

Foss, N. (1998) The competence-based approach: Veblenian ideas in the modern theory of the firm, Cambridge Journal of Economics 22: 479-498.

Groenewegen, J. (1995) A changing japanese market for corporate control, in J. Groenewegen, C. Pitelis and S. E. Sjöstrand (Eds) On Economics Institutions. European Association for Evolutionary Political Economy, Cambridge, pp. 213-230.

Grotz, R. and Braun, B. (1997) Territorial or trans-territorial networking: spatial aspects of technologyoriented cooperation within the german mechanical engineering industry, Regional Studies 31: 
545-557.

Guerrien, B. (1990) Quelques réflexions sur institutions, organisations et histoire, Économie Appliquée 43: 89-110.

Hodgson, G. (1988) Economics and Institutions: A Manifesto for a Modern Institutional Economics, Polity Press, Cambridge.

Hodgson, G. (1996) Corporate culture and the nature of the firm, in J. Groenewegen (Eds) Transaction Cost Economics and Beyond. Kluwer Academic Publishers, Boston / Dordrecht / London, pp. 249-269.

Hodgson, G. (1997) The ubiquity of habits and rules, Cambridge Journal of Economics 21: 663-684.

Hodgson, G. (1998) The Approach of Institutional Economics, Journal of Economic Literature 36: 166192.

Jayet, H. (1996) Quelle organisation économique des espaces ruraux?, Revue d'Economie Régionale et Urbaine 2: 249-261.

Johnson-Laird, P. (1994) L'ordinateur et l'esprit, Odile Jacob, Paris.

Kechidi, M. (1996) Coordination inter-entreprises et relations de sous-traitance: le cas d'Aerospatiale, Revue d'Economie Régionale et Urbaine 1: 99-120.

Kechidi, M. and Panadero, Y. (1994) Le secteur aéronautique et les transformations de la soustraitance régionale in J.P. Gilly and C. Dupuy. (Eds) L'industrie en Midi-Pyrénées: entre tradition et modernité. Presses de l'Université des Sciences Sociales, Toulouse, pp. 93-134.

Kirat, T. and Lung, Y. (1995) Innovations et proximités: le territoire, lieu de déploiement des processus d'apprentissages, in N. Lazaric, J. M. Monnier and B. Paulre (Eds) Coordination économique et apprentissage des firmes. Economica, Paris, pp. 207-227.

Larré, F. (1994) Mécanismes et formes de coordination interentreprises, l'analyse d'un réseau de sous-traitance, thesis, Université des Sciences Sociales, Toulouse.

Livet, P. and Thevenot, L. (1994) Les catégories de l'action collective, in A. Orlean (Ed), Analyse économique des conventions. Presses Universitaires de France, Paris, pp. 139-167.

Loasby, B. (2000) Market institutions and economic evolution, Journal of Evolutionary Economics 10: 297-309.

Loasby, B. (1999) Cognition, Capabilities and Co-operation, Conference Co-operative Behaviours, Ecole de Sophia Antipolis, Nice, November.

Menard, C. (1990) L'Économie des Organisations, series Repères, La Découverte, Paris.

Menard, C. (1994) La nature de l'innovation organisationnelle, éléments de réflexion, Revue d'Économie Industrielle, special issue Économie industrielle: développements récents, July, 173-192.

Nelson, R. R. (1995) Recent Evolutionary Theorizing About Economic Change, Journal of Economic Literature, 33: 48-90.

Nelson, R. R. and Winter, S. G. (1982) An Evolutionary Theory of Economic Change, Harvard 
University Press, Cambridge.

Penrose, E. (1952) Biological analogies in the theory of the form, American Economic Revue 52: 804819.

Piaget, J. (1970) L'Épistémologie génétique, Presses Universitaires de France, Paris.

Picq, J. (1990) Les ailes de l'Europe, Fayard, Paris.

Renault, M. (1995) Communication, interactions et coordination des comportements, Conference La connaissance dans la dynamique des organisations productives, CEFI-GRACSE-GREQAMLEST, Aix-en-Provence, September.

Reynaud, J. D. (1993) Les règles du jeu. L'action collective et la régulation sociale, series Sociologie, Armand Colin, Paris.

Reynaud, B. (1997) L'indétermination de la règle et la coordination. Réflexions sur l'instauration d'une règle salariale dans un atelier de maintenance, in $\mathrm{B}$. Reynaud (Eds) Les limites de la rationalité. Les figures du collectif. La Découverte, Paris, pp. 235-253.

Rutherford, M. (1995) The Old and the New Institutionalism: Can Bridges be Built?, Journal of Economic Issues 29: 443-451.

Sjöstrand, S. E. (1995) Towards a theory of institutional change, in J. Groenewegen, C. PItelis and S.E. Sjöstrand (Eds) On Economics Institutions. European Association for Evolutionary Political Economy, Cambridge, pp. 19-43.

Talbot, D. (1998) Les principes institutionnalistes des dynamiques industrielle et spatiale, le cas du groupe Aerospatiale, thesis, Université des Sciences Sociales, Toulouse.

Varela, F., Thompson, E. and Rosh, E. (1993) L'inscription corporelle de l'esprit, Sciences cognitives et expérience humaine, Seuil, Paris.

Veblen, T. (1899) Preconceptions of Economic Science, II, Quarterly Journal of Economics13: 396426.

Veblen, T. (1909) The Limitations of Marginal Utility, Journal of Political Economy, 17: 230-249.

Waller, W. (1988) The Concept of Habit in Economic Analysis, Journal of Economics Issues 22: 113126.

Williamson, O. E. (1985) The Economic Institutions of Capitalism, The Free Press, Macmillan, New York.

Williamson, O. E. (1998) The Institutions of Governance, American Economic Review 88: 75-79. 